\title{
The theoretical justification for the fractionation of bulk materials during separation
}

\author{
Valery Piven ${ }^{l, *}$ \\ ${ }^{1}$ Tyumen industrial University, Volodarskogo Str., 38, Tyumen, 625000, Russia
}

\begin{abstract}
In separating lines at different stages of the technological process is carried out fractionation of the bulk material. These different quality streams subsequently processed on the working bodies or machines that are more suited for a specific faction. Fractionation can increase productivity, reduce costs, reduce the amount of material being processed through the working bodies of the passes. Criteria for selection of the working body for fractionation and its place in the production line depends on many factors and insufficiently developed. The aim of this work is to determine the criteria for evaluating the effectiveness of the working body for the fractionation of the raw material on the basis of a possible increase productivity throughout the production line. The curves obtained by calculation, allow us to estimate the total increase in line speed. Obtained dependence can be used for calculations of separation processes of granular mixtures in the production of building materials, food industry, powder metallurgy, pharmaceutical and other.
\end{abstract}

\section{Introduction}

In various branches of industry in the preparation of raw material, intermediate, or bring the final product to the applicable regulatory requirements separation of bulk materials.

In the construction industry for the classification of the particle size of sand, loose construction mixtures vibrating screens are widely used [1-10]. Similar equipment used in the mining industry [11, 12], industry [13], food [14, 15]. For separation of fine materials used air separation [16-27], which is very often used in conjunction with the sieve by separation [28].

The problem of quality of separation exists in the preparation of seed in agricultural production [29-31] and the allocation of hazardous contaminants in the milling and grinding industry. For example, biological or chemical composition when components like mixture can be separated by means of a mechanical action only when it is accompanied by various physical and mechanical properties. The difficulty lies in the fact that the shared components have very similar physic-mechanical properties. Therefore, there is a need for separation of aggregate material separation characteristics.

\footnotetext{
* Corresponding author: pivenvv@yandex.ru
} 
In this regard, the bulk separation of mixtures in most cases it is necessary to use the largest number of separation characteristics, use separating the working bodies where the combined effect of using these features $[28,32,33]$.

For proper selection of the working bodies in the preparation of technological lines required information about the numerical values of the quantities characterizing the properties of the components to be separated, as well as their concentration [34].

The organization of the process promising avenue is the use of fractional separation technologies $[28,32,35]$. The essence of these technologies is to separate the source of the bulk material of different quality in its composition fraction (part). Further processing of these fractions is carried out separately. Fractions obtained processing technology must take into account their quality composition.

Due to the necessity of using a starting material for separation of various features in traditional separation flowsheets all the material is passed through a non-specified number of working bodies successively for various

purposes. Impurity phases allocated to each operating element and the purified material is obtained at the outlet of the production line.

Actual performance separating lines in the real world can be 1.5 - 3.0 times lower than the rating. The main reasons for this is underutilization of the performance of individual machines and equipment as a result of their consistent connection and incompleteness in quality cleaning process. It requires multiple separated material pass through the working bodies. Depending on the specific conditions to limit the performance of the entire line can be any actuator. For example, the lower sieve [36].

Incomplete utilization of separating machines and working bodies because of their rigid technological communication with each other causes the lower separating capacity in general of the whole line. The main reasons for the above-mentioned drawbacks of the existing production lines is a discrepancy between the required time separation of the material to the actual time of its location on your body. The excess of the required time separation valid necessitates re-treating the material and determines their ratio multiplicity processing.

\section{Methods}

The required separation time is determined by the physical and mechanical properties of the raw material components, the required quality of the finished material, its interest yield, specific load, kinematic parameters of working bodies. Improving the ability of a separating process lines for the separation of bulk materials by increasing the number of working bodies of the same type or set of parallel rows of leads to an increase in the cost parameters.

Improving the quality of the separation process and performance improvement, ceteris paribus is possible due to the pre-redistribution component cereal mixture between the factions.

When the sieve separators increase the specific load leads to an increase in the efficiency of a large selection of light impurity at a two-tier arrangement of sieves. This is due to impurities in the floating layer of light moving over the screen material selection and it is similar to the upper screen. Increased pressure on the lower or main sieve leads to difficulty small components pass through the layer of separated material [37, 38, 39]. As a result of this process, separation efficiency is reduced.

Sub-optimal loading of separating individual working parts may occur when changing the percentage of impurities in the starting material. Therefore, before supplying the source separated material to the main separating machine is necessary to ensure a stable percentage of the material. 
Divide the source material on the grain fractions mind of impurities or highlight individual fractions in pure form is very difficult due to the greater number of its constituent components, imperfections separating bodies are constantly changing the composition of the starting material.

In most cases, a fraction containing the same components as the starting material, but in different proportions. Therefore, separation is necessary to use all the major types of working bodies (air channel, a sieve, Trier). For optimum loading of each of these working elements must simultaneously fractionation flexible regulation resulting volume fractions and their quality according to the state of the starting material. The need for such a regulation is dictated by constantly changing the composition of the starting material.

Fractionation of great importance should be allocated to the choice of the division attribute at fractionation, sequence location and layout of the working bodies in the process line. Versatility separating machines with combined working bodies reduces their range, but it limits the possibilities of separating the individual working bodies due to their rigid connection with each other.

Comparative analysis of the ability of the pitch separating the working bodies in the separation on the basic features (aerodynamic properties, thickness, width, length) shows that in real terms the worst of all possible uses of the air flow. Process air flow efficiency can be as little as $15-30 \%$.

The reasons for the low efficiency of the air flow of the work are the design features of the use of the air channelas an additional operating element in the sieve separating machines. This leads to uneven loading airflow velocity unevenness of its fields, the high concentration of components in the separation zone, setting process complexity. Maximum capacity of separating the air flow is achieved when the constructive development of air channels of individual working bodies. In this case, you can use the optimum cross-section of the air channel, providing the most qualitative separation.

When choosing the location of the sequence separating the working bodies in the process lines in the first stage should be preferred to air flow, i.e. In. Air flow performance is less dependent on humidity and contamination of the starting material.

When working on the production lines fractional schemes recommended to allocate to various waste from 5 to $30 \%$ of the components of the main product $[32,28]$. Isolation of a fraction in the first stages of processing can improve the ability of separating the following working bodies and unload process line.

From the above analysis that the raw material be fractionated using a sieve or an air flow, taking into account the physical-mechanical properties of its components. Possibly also two-step fractionation: first step - the air flow, the second - sieve. Fractionation should be a preparatory operation before the material by separation in the subsequent working bodies in order to enhance their ability to pitch. It is necessary to carry out a flexible regulation of quality and volume of fractions to reduce the influence of the changing composition of the starting material.

To study the effectiveness of a fractionation process of reception, enhancing the ability of separating working bodies, it is necessary to consider theoretically the process of separating the starting material of different quality fraction. For comparison we will base the parallel operation of two similar screens having the width $S$ and the length $L_{I}$ (Fig. 1). The starting material stream is divided into two equal in scope and quality parts. Each sieve is $Q_{0}$ performance. Total capacity of the two screens is $Q_{l}$. The original content of impurities in the feed to the sieve starting material denoted $D_{0}$. 


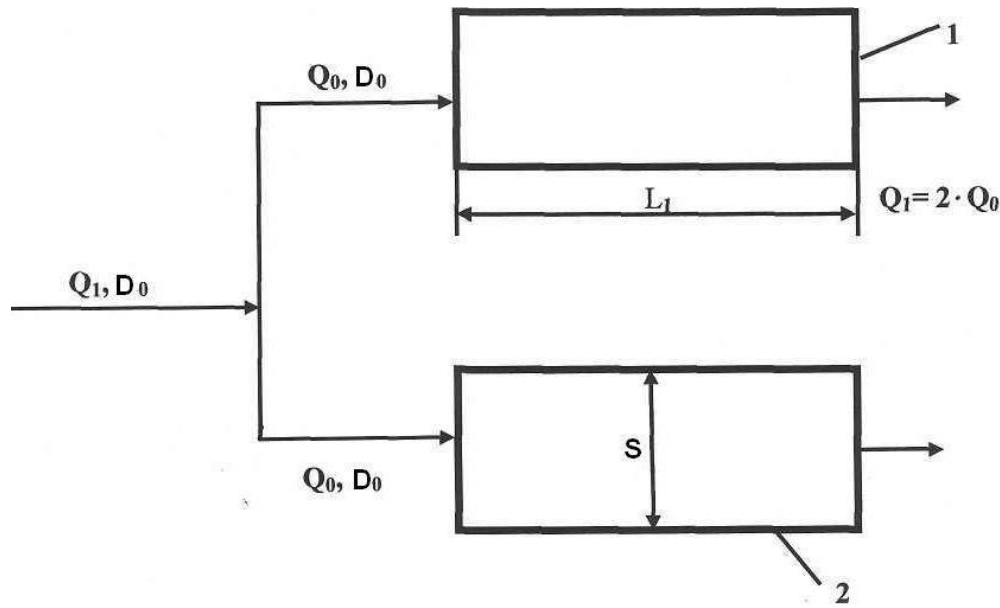

Fig. 1. Schematic of the location of the working bodies in the base case: 1,2 - screens

When working on a fractional scheme (Fig. 2) in-line included a working body for fractionation. Performance for input on this body is $Q^{\prime}$ with the same source material debris $D_{0}$. At the exit from the working member to fractionate the starting material is divided into two fractions and applied to is the same as in the basic embodiment of sieve. The amount of starting material fed to the sieve 1 is $Q^{\prime} \cdot \varphi$. On the sieve 2 - $Q^{\prime} \cdot(1-$ $\varphi)$. The magnitude $\varphi$ It is determined by the proportion of the output of the first main fraction, which has a contamination $D_{01}$. Infestation of the second fraction is equal to the value of $D_{02}$.

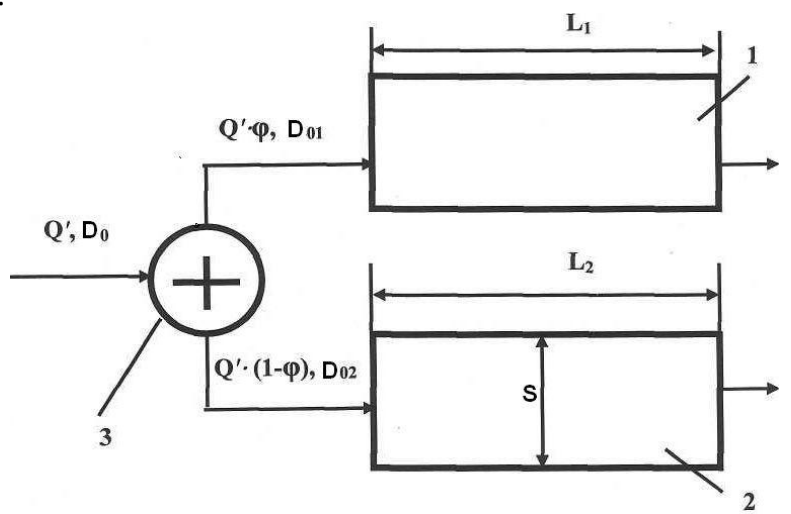

Fig. 2. Scheme of the location of the working bodies in the fractionation: 1, 2 screens, 3- fractionating working body

Assume that redistributes fractionating actuator impurity of the first fraction to the second so that the clogging of the first fraction is proportional to its output. Then

$$
\begin{gathered}
D_{01}=D_{0} \cdot \varphi \\
D_{02}=D_{0} \cdot(1-\varphi) .
\end{gathered}
$$




\section{Results and discussion}

Let the total amount of impurities extracted from the screen area during the separation unit, both processing lines are equally well and $Q_{R}$. In this case, a more rational use of the working bodies of technological lines by fractionation will increase their relative performance. Specific performance sieves first production line (Fig. 1) will be determined by the formula:

$$
G_{u 0}=Q_{0} / S \cdot L \text {. }
$$

The second line (Fig. 2) - using the formula:

$$
G_{u}=Q^{\prime} /\left(S \cdot L_{1}+S \cdot L_{2}\right) .
$$

Factor increasing the production rate of the second line with the first [14]:

$$
\eta_{Q}=G_{u} / G_{u 0} .
$$

Self-sorting time (time sifting through a small layer of material components located on the screen (Fig. 3)) is given by [14]:

$$
t_{0}=(h-\Delta h) / W_{z}
$$

where $h$ - the height of the layer of material on the sieve, $m$;

$\Delta h$ - the height of the elementary layer one particle in $m$;

$W z$ - vertical movement speed of the fine particles in the layer of material $\mathrm{m} / \mathrm{s}$.

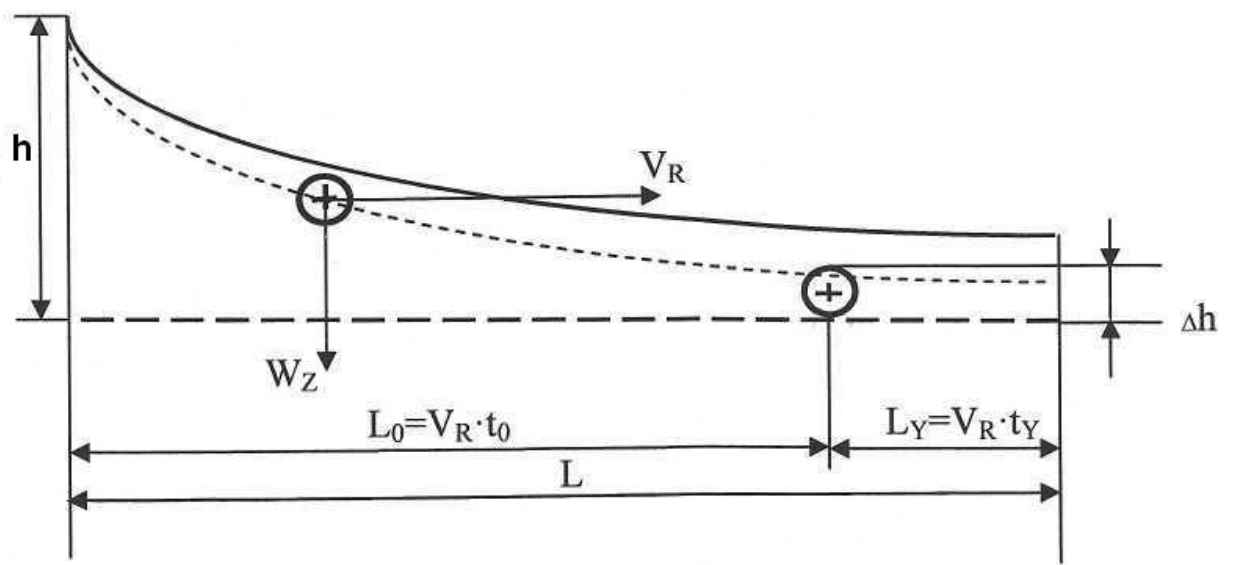

Fig. 3. Scheme of movement of small component in a layer of material being separated on the sieve: L0 -the length of the screen, on which the screening of small components through the material layer; LY - the length of the screen, on which there is sifting through a fine mesh sieve component

$$
W_{z}=r \cdot \omega\left(m_{0}(\Delta-1) g\right) \cdot F_{V}^{-1}\left[\left(m_{0}(\Delta-1) / m_{1}(1-\delta)^{1 / 2}\right)-\left(F_{h} /\left(m_{1} \cdot r \cdot \omega^{2}\right)\right)^{2}\right]^{1 / 2}
$$

where $r$ - the radius of the trajectory of the medium point, $m$;

$\omega$ - the frequency of the oscillation sieve, $\mathrm{rad} / \mathrm{s}$;

$m_{0}$ - the mass media in an amount equal to the volume of the particle, $\mathrm{kg}$;

$\Delta=\rho / \rho_{0}$ - the ratio of the small component and density of the surrounding environment;

$F v$ - the power of immersion resistance in the vertical direction, $N$;

$\mathrm{Fh}$ - the power of immersion resistance in the horizontal direction, $N$; 
$m 1=m+m^{\prime}-$ the effective mass of the particles consisting of particle mass and added mass in $\mathrm{kg}$;

$\delta$ - dimensionless parameter showing which part of the drag force is the difference in the forces of gravity and the particle medium in the volume of the particle.

Performance of the first line (Fig. 2) with the expression (6), subject to the screening of small components through a layer of Material having a sieve at the beginning of the thickness $H$, is defined as

$$
Q_{1}=\left(W_{z} \cdot L_{1} / V_{R}+\Delta h\right) \cdot S \cdot V_{R} \cdot \rho,
$$

where $V_{R}$ - the rate of separated material along the sieve, $\mathrm{m} / \mathrm{s}$.

$\rho$ - bulk density of the separated material, $\mathrm{kg} / \mathrm{m}^{3}$. Performance of the second line, if all fines sieving through sieve material layer 1 (Fig. 2)

$$
Q^{\prime}=\left(W_{z}^{\prime} \cdot L_{1} / V_{R}+\Delta h\right) \cdot S \cdot V_{R} \cdot \rho_{0} / \varphi,
$$

Where $W_{z}^{\prime}$ - vertical movement speed pattern for the small particles in the material layer shown in Fig. $3 \mathrm{~m} / \mathrm{s}$.

2 on the sieve (Fig. 2) enters the starting material with a high content of small components. Therefore, for more efficient separation of impurities therefrom intake material to a sieve 2 must be carried out in one elementary layer. Minor impurities sieve sieved 2 begin after contact with a sieve. Therefore, the length of the screen 2 can be represented as

$$
L_{2}=t_{2} \cdot V_{R},
$$

where $t_{2}$ - residence time of the material on the sieve with.

Time $t_{2}$ is determined from the relationships obtained in [14]

$$
t_{2}=-\ln \left(1-Q_{R 2} / F_{N 2}\right) / C_{Y 2} .
$$

Where $F_{N 2}$ - The impurity concentration in the lower sieve layer 2 (Figure 2).

$C_{Y 2}$ - Intensity factor screening, $1 / s$.

Impurities extracted from both sieves unit area during separation, equal to the sum of impurities with the first and second sieves:

$$
Q_{R}=Q_{R 1}+Q_{R 2}
$$

In view of the initial content of impurities $\left(D_{0}\right)$ and the regulatory process efficiency $(N)$

$$
Q_{R}=N \cdot D_{0} \cdot Q_{1} /\left(S \cdot V_{R}\right) \text {. }
$$

The impurity concentration in the second elementary layer the sieve

$$
F_{N 2}=D_{02} \cdot \Delta \cdot \rho_{0},
$$

In view of (12) - (14) the expression (11) takes the following form:

$$
t_{2}=-C_{Y 2}^{-1} \cdot \ln \left[1-\left(N \cdot D_{0} \cdot Q_{1} /\left(S \cdot V_{R}\right)-Q_{R 1}\right)\left(D_{02} \cdot \Delta \cdot \rho_{0}\right)^{-1}\right] .
$$

The amount of $Q_{R l}$, a member of the expression (12), according to [14] is defined as

$$
Q_{R 1}=D_{01} \cdot \rho_{0}\left[W_{z}^{\prime} \cdot L_{1} / V_{R}+\left(\Delta h-W_{z}^{\prime} / C_{Y}\right) \cdot\left(1-\exp \left(-C_{Y} \cdot L_{1} / V_{R}\right)\right)\right]
$$

In view of the above expression for determining dependency ratio increased productivity (5) takes the following form:

$$
\left.\left.\eta_{Q}=\left[\left(W_{z}^{\prime} \cdot L_{1} / V_{R}+\Delta h\right) L_{1}\right\rfloor \varphi\left(L_{1}+t_{2} V_{R}\right)\left(W_{z} \cdot L_{1} / V_{R}+\Delta h\right)\right]^{-1} .17\right)
$$

\section{Conclusions}

Expressions (12) - (17) are sufficient conditions for determining the appropriateness of a working body in technological lines for fractionation. The resulting expression is possi- 
ble to determine depending on the initial state of the material being separated, size of the sieve surfaces speed sieve material.

The feasibility of using a specific working body for fractionation will also be determined by the share of redistribution of impurities between fractions $(\varphi)$, which provides the working body.

When changing the qualitative composition of the starting material with flexible processing schemes can be implemented traditional streaming technology and technology fractional fractionation on one or more of its stages.

\section{References}

1. Blekhman I.I. Teoriya vibracionnyh processov $i$ ustrojstv. Vibracionnaya mekhanika $i$ vibracionnaya tekhnika [The theory of vibrational processes and devices. Vibrational mechanics and vibrational technique]. Saint-Petersburg: Izdatel'skij dom «Ruda i metally», 2013. 640 p. (rus)

2. Brik E.R. Issledovanie kinetiki frakcionirovaniya sypuchih stroitel'nyh materialov na grohotah s mnogoyarusnoj komponovkoj sit [The study of the kinetics of fractionation of bulk construction materials on the screens with a multi-tiered layout of screens]. Dis. ... kand. tekhn. nauk [The dissertation on competition of a scientific degree of candidate of technical Sciences]. Ivanovo.: IGASU, 2011. 127 p. (rus)

3. Vavilov A.V., Eleukenov M.T. Modelirovanie processov grohocheniya i konstrukcij grohotov dlya polucheniya kachest-vennyh zapolnitelej pri razdel'nom prigotovlenii betonov [3.Vavilov A. V., Eleukenov, M. T. Modelirovanie processov grohocheniya i structures grohotov dlya polucheniya kachest-vennyh zapolnitelej in razdel'nom prigotovlenii betonov]. Vestnik VKGTU. № 2. 2014. Pp. 31-34. (rus)

4. Vajsberg L. A., Akimova A. V., Ivanov K. S. Novye metody modelirovaniya i rascheta vibracionnyh grohotov i groho-tov-separatorov [New methods of modeling and calculation vibrating screens and screeners-separators]. Sovremennoe mashinostroenie. Nauka i obrazovanie. Saint-Petersburg: Izd-vo SPbGPU, 2013. № 3. Pp. 651-658. (rus) 5. Vasil'ev S.B., Kolesnikov G.N., Kul'bickij A.V. Logisticheskoe uravnenie kak model' frakcionirovaniya drevesnoj shchepy metodom rasseva [The logistic equation as a model for the fractionation of wood chips by the method of sieving]. Materialy tret'ej mezhdunarodnoj nauchno-prakt. internet-konf. «Lesa Rossii XXI veka» [Materials of the third international scientific-pract. Internet Conf. "Forests of Russia in XXI century"]. Saint-Petersburg: Izd-vo SpbGLTA, 2010. Pp. 236-239. (rus)

6. Cundall P.A., Strack O.D.L. A distinct element model for granular assemblies. Geotechnique. 1979. No 29. Pp. 47-65.

7. $\quad$ Ferrara G., Preti U., Schena G.D. Modelling of screening operations. Intern. J. of Mineral Processing. 1988. 22. 1-4. Pp. 193-222.

8. Kim T-H., I. Maruta I., Sugie T. A simple and efficient constrained particle swarm optimization and its application to engineering design problems. Journal of Mechanical Engineering Science. 2010. Vol. 224. No C2. Pp. 389-400.

9. Ogurcov V. A., Ogurcov A.V., Mitrofanov A.V., Aleshina A.P. YAcheechnaya model' psevdoozhizheniya $\mathrm{v}$ tekhnologii pro-izvodstva stroitel'nyh materialov [A nonline ar cell model of fluidization in the technoogy of construction materials production]. Stroitel'stvo i rekonstrukciya [Construction and reconstruction]. Iss. 5 (43). 2012. Pp. 68-74. (rus)

10. Fedosov S.V., Mizonov V.E., Ogurcov V.A. Modelirovanie processa klassifikacii polidispersnyh materialov na vibrogrohotah [Modeling of the process of classification of polydisperse materials in vibrating screens]. Stroitel'nye materialy [Building materials]. 2007. № 11. Pp. 26-28. 
11. Mayer F.W. Fundamentals of a potential theory of the jigging process. VII Int. Min. Proc. Congr. New-York. 1964. Pp. 78-86.

12. Nikiforova L.V., Matveev A.I., Slepcova E.S., YAkovlev B.V. Matematicheskoe modelirovanie processa otsadki [Mathematical modelling of the jigging process]. Matematicheskie zametki SVFU [Mathematical notes SVFU]. 2014. T. 21. № 1. Pp. 106-112. (rus)

13. Slepcova E.S., Fedoseev S.M. Izvlechenie zolota iz magnitnyh shlihov otsadkoj $\mathrm{v}$ pole dejstviya polyusoperemennogo magnitnogo polya // Gornyj informacionno-analiticheskij byulleten' [Mining information-analytical Bulletin]. 2015. № 7. Pp. 260-264. (rus)

14. Gortinskij V. V., Demskij A. B., Boriskin M. A. Processy separirovaniya na zernopererabatyvayushchih predpriyatiyah [Processes of separation of grain handling companies]. Moscov: Kolos, 1980. 304 p. (rus)

15. CHurin YU. G. Primenenie teorii separacii pri proektirovanii separatorov vibracionnogo tipa [Application of the theory of separation when designing separators, vibrating]. Vestnik Moskovskogo gosudarstvennogo agroinzhenernogo universiteta [Bulletin of Moscow state Agroengineering University]. Moscov.: RGAU, 2010. № 1. Pp. 29-32. (rus)

16. Ponomarev V.B. Pererabotka metallurgicheskih shlakov metodom pnevmaticheskoj separacii [Processing of metallurgical slags by means of pneumatic separation] Stal' [Steel]. 2015. № 2. Pp. 82-83. (rus)

17. Ponomarev V.B. Vydelenie uzkih frakcij poroshkov metodom vozdushnoj klassifikacii [The allocation of narrow fractions of powders by the method of air classification]. Innovacionnye tekhnologii obogashcheniya mineral'nogo $i$ tekhnogennogo syr'ya. Materialy nauchno-tekhnicheskoj konferencii [Innovative technologies of enrichment of mineral and technogenic raw materials. Materials of the scientifictechnical conference]. 2015. Pp. 62-65. (rus)

18. Ponomarev V.B. Razdelenie shamotnyh poroshkov metodom vozdushnoj separacii [Separation of refractory powders by the method of air separation]. Novye ogneupory [New refractories]. 2014. № 10. Pp. 68-69. (rus)

19. Bogdanov D.V., Dubrovskij V.V., Ponomarev V.B., Gavrilenko A.V. Optimizaciya tekhnologicheskih parametrov processa frakcionirovaniya sypuchih materialov []. EHnergosberegayushchie tekhnologicheskie kompleksy $i$ oborudovanie dlya proizvodstva stroitel'nyh materialov. Mezhvuzovskij sbornik statej. [Energy saving technological complexes and equipment for manufacture of building materials. Interuniversity collection of articles]. Belgorod: 2015. Pp. 38-41. (rus)

20. Ponomarev V.B. Suhaya pererabotka othodov kamnedrobleniya [Dry waste recycling crushing stones]. Gornyj zhurnal [Mining journal]. 2015. № 12. Pp. 50-52. (rus)

21. Lanzerstorfer C., Kröppl M. Air classification of blast furnace dust collected in a fabric filter for recycling to the sinter process. Resources, Conservation and Recycling. 2014. Vol. 86. Pp. 132-137.

22. Kleiv R. A. Value enhancement of olivine process dust through air classification. International Journal of Minerals, Metallurgy, and Materials. 2012. Vol. 19. Iss. 3. Pp. 185-191.

23. Felk A. Fine-Milling and Air Classification of Ceramic Materials by the Dry Method. Glass and aceramics. 2014. Vol. 71. Iss. 3. Pp. 92-95.

24. Shishkin S. F., Dzyuzer V. Ya., Shishkin A. S. Air Classification of Sands for the Glass Industry. Glass and Ceramics. 2001. Vol. 58. Iss. 11. Pp. 370-373.

25. Barsky E. Efficacy of separation of a pourable material. High Temperature. 2009. Vol. 47. Iss. 6. Pp. 822-828. 
26. Borisevich V., Borshchevskiy M., Andronov I., Senchenkov S. Assessment of parameters of gas centrifuge and separation cascade basing on integral characteristics of separation plant. Nuclear Engineering and Design. 2013. Vol. 265. Pp. 1066-1070.

27. Mizonov V.E., Ushakov S.G., Barochkin E.V. Aehrodinamicheskaya klassifikaciya poroshkov [Aerodynamic classification of powders]. Ivanovo: PresSto, 2014. 260 p. (rus)

28. CHumakov V.G. Delenie zernovogo voroha na frakcii pnevmoreshetnym separatorom [The division of the grain heap into fractions pnevmaticheskim separator]. Traktory i sel'hozmashiny [Tractors and farm machinery]. 2011. № 12. Pp. 31-33. (rus)

29. Kosilov N.I., Piven V.V. Tekhnologicheskie vozmozhnosti modernizacii i sozdaniya perspektivnyh potochnyh linij dlya posleuborochnoj obrabotki zerna [The technological possibilities of modernization and the creation of advanced production lines for post-harvest grain handling]. APK Rossii [APK Russia]. 2000. T. 31. P. 28. (rus)

30. Kosilov N.I., Piven V.V. Povyshenie ehffektivnosti predvaritel'noj ochistki zerna $\mathrm{v}$ hozyajstvah [Improving the efficiency of precleaning grain farms]. Ural'skie nivy [Ural fields]. 1987. № 3. Pp. 54-55. (rus)

31. Piven V.V., Umanskaya O.L. Osnovnye napravleniya sovershenstvovaniya tekhnologii i tekhniki dlya posleuborochnoj obrabotki zerna [The main directions of improvement of technology and machinery for post-harvest grain handling]. Hranenie i pererabotka sel'hozsyr'ya [Storage and processing of agricultural products]. 2003. № 8. Pp. 205-208. (rus)

32. Piven V.V. Sovershenstvovanie tekhnologicheskogo processa ochistki zerna frakcionirovaniem zernovogo voroha po aehrodinamicheskim svojstvam [Improvement of technological process of cleaning the grain by fractionation of grain heap on the aerodynamic properties]. Avtoref. diss. ... dokt. tekhn. nauk [Abstract of dissertation on competition of a scientific degree of doctor of technical Sciences]. Chelyabinsk, 1995. 36 p. (rus)

33. Piven V.V., Umanskaya O.L. Osnovnye tendencii sovershenstvovaniya frakcionnyh tekhnologij ochistki zerna [Main trends in improvement of the fractional technology of grain cleaning]. Problemy sovremennoj nauki i obrazovaniya [Problems of modern science and education]. 2013. № 1 (15). Pp. 39-42. (rus)

34. 34.Mizonov, V.E. Ogurcov V.A., Fedosov S.V., Ogurcov A.V. Processy separacii chastic $v$ vibroozhizhennom sloe: mo-delirovanie, optimizaciya, raschet [The processes for the separation of particles in vibramicina layer: modeling, optimization, design]. Ivanovo: 2010. 192 p. (rus)

35. Zlatev M. Equipment concept. Aufbereitungs-Technik/Mineral Processing. 2016. Iss. 11.

36. Bauman V.A. Vibracionnye mashiny $i$ processy $v$ stroitel'stve [Vibration machines and processes in construction]. Moscov: Vysshaya shkola, 1977. 255 p. (rus) 37. Matveev A. I., Nikiforova L. V., Slepcova E. S., YAkovlev B. V. Issledovanie raspredeleniya tyazhelyh frakcij v ko-leblyushchejsya sypuchej srede [The study of the distribution of heavy fractions in an oscillating granular medium]. Nauka i obrazovanie [Science and education]. 2016. № 2 (82). Pp. 21-26. (rus)

38. Ogurcov V.A., Gorohova E.R., Makarova V.M., Medvedeva P.A. Vibracionnyj grohot kak mnogoproduktovyj klassi-fikator: kinetika izvlecheniya frakcij [Vibrating screen as a multiproduct classifier: kinetics of extraction fractions]. Stroitel'stvo i rekonstrukciya [Construction and reconstruction]. 2011. № 4(36). Pp. 47-50. (rus)

39. Ogurcov V.A. Stohasticheskaya model' raspredeleniya prohodovyh chastic v sloe sypuchego materiala pri vibrogroho-chenii [Stochastic model distribution Prokopovych particles in the layer of bulk material when using vibration screens]. Stroitel'nye materialy [Building materials]. 2007. № 11. Pp. 38-39. (rus) 